\title{
Replies
}

\section{Defensive Stock Repurchases and the Appraisal Remedy}

\author{
Michael Bradley† and Michael Rosenzweig†t
}

\section{INTRODUCTION}

In an article recently published in the Harvard Law Review, ${ }^{1}$ we made essentially four points: (1) defensive open market repurchases should be outlawed because they exert precisely the pressures on target shareholders that Congress sought to eliminate by adopting the Williams Act in 1968; (2) defensive open market repurchases should be outlawed because target managers can use them to defeat value-increasing takeover bids; (3) defensive self-tender offers, subject to certain conditions, should continue to be legal because target managers can use them to defeat value-decreasing but not value-increasing takeover bids; and (4) defensive self-tender offers, subject to certain conditions, should continue to be legal because they tend to "even the playing field" in corporate control contests by enabling target managers to compete fairly with interfirm bidders for the right to manage the target's resources.

In a comment appearing in this Journal, ${ }_{2}$ Professors Gordon and Kornhauser challenge these four conclusions. Specifically, they argue that "target stock buybacks are unlikely to increase shareholder wealth as a general matter and, on a shareholder wealth criterion, should not be per-

$\dagger$ Associate Professor of Finance, Graduate School of Business Administration, and Adjunct Associate Professor of Law, University of Michigan. B.A. 1969, University of Idaho; M.B.A. 1974, Syracuse University; Ph.D. 1979, University of Chicago.

H Associate Professor of Law, University of Michigan. A.B. 1973, University of Michigan; J.D. 1976, Columbia University. We wish to acknowledge the generous support of the W.W. Cook Endowment of the University of Michigan and the University of Michigan Graduate School of Business Administration.

1. Bradley \& Rosenzweig, Defensive Stock Repurchases, 99 HARv. L. REv. 1377 (1986).

2. Gordon \& Kornhauser, Taheover Defense Tactics: A Comment on Two Models, 96 YAlE L.J. 295 (1986). 
mitted as a defensive tactic."s Thus, although Gordon and Kornhauser ultimately agree with us that defensive open market repurchases should be barred, they would go further and outlaw defensive self-tenders as well. ${ }^{4}$

The Gordon and Kornhauser critique is unpersuasive. First, in reexamining defensive open market repurchase programs, they confuse the firm's investment/production decisions with its financing decisions, and as a result provide no new insights into either the uses or the abuses of such repurchase programs. Second, in analyzing defensive self-tender offers, they overstate the likely costs of our proposal and slight the benefits that defensive self-tenders can provide. More specifically, they exaggerate problematic aspects of the conditions that we suggested for such transactions, and mistakenly conclude that the valuable function we ascribed to defensive self-tenders is adequately served by other mechanisms.

Of the conditions that we would impose on defensive self-tender offers, the most objectionable to Gordon and Kornhauser is our proposal to nullify the target shareholders' appraisal remedy in the context of such transactions. ${ }^{5}$ They attack this suggestion as radical and conceptually unjustifiable, ${ }^{6}$ and criticize us for revealing this feature of our scheme only "in the form of a footnote." We agree with their implicit point that this aspect of our proposal deserves fuller discussion than we were able to provide in our article, and therefore welcome this opportunity to explore the issue further. Indeed, most of our comments here will concern the role of the appraisal remedy and its proper application in corporate control contests. Our conclusion, however, remains unchanged: The appraisal remedy should be unavailable to target shareholders once target management has effected a defensive self-tender.

This reply is organized as follows. In Part II, we respond to Gordon and Kornhauser's examination of defensive open market repurchases by showing that their criticism of our discussion stems from a flawed analysis that confuses the firm's investment/production decisions with its financing decisions. In Part III, we review our analysis of defensive self-tender offers and our claim that such transactions should be permitted, subject to certain conditions. We illustrate the importance of defensive self-tenders to the efficiency of the market for corporate control and describe how their availability can help prevent value-decreasing interfirm bids. We then discuss Gordon and Kornhauser's proposal to outlaw defensive self-tender offers. We argue that such a ban would unfairly advantage interfirm bid-

\footnotetext{
3. Id. at 297.

4. Id. at 311 .

5. Bradley \& Rosenzweig, supra note 1 , at 1419 n.150.

6. Gordon \& Kornhauser, supra note 2, at 309.

7. Id. at 311 .
} 
ders and, as a result, could allow corporate raiders to expropriate the wealth of target shareholders. We also respond specifically to Gordon and Kornhauser's criticism of our proposal to nullify the appraisal remedy once target managers make a defensive self-tender; we show that the constraints imposed by appraisal statutes on interfirm bidders can empower target managers to defeat value-increasing takeover bids, and argue further that target shareholders do not need the appraisal remedy in the context of a defensive self-tender.

Finally, in Part IV, we briefly present three alternative reforms of the appraisal remedy that would accomplish our overall objective of "evening" the competition between target managers and interfirm bidders in control contests.

\section{Defensive Open Mariset Repurchases}

\section{A. Review of the Bradley and Rosenzweig Analysis}

In our article, we argued that defensive open market repurchase programs should be outlawed. More specifically, we suggested that defensive stock repurchases should be permitted only if effected as self-tender offers and subjected to the same requirements that are imposed on interfirm bids.

Our proposal is based on two related propositions. First, as currently regulated, defensive open market repurchases create precisely the pressures on shareholders that led Congress to regulate tender offers; as firstcome, first-served premium offers, defensive open market repurchases are "tender offers," as Congress understood that term. ${ }^{8}$ Second, because of the coerciveness of defensive open market repurchases under current regulations, such repurchases can help target managers defeat value-increasing interfirm bids..$^{9}$ This gives target managers an advantage in control contests and can impede the flow of corporate resources to their highest valued uses. Our proposal to regulate all defensive stock repurchases as selftender offers (subject to certain conditions discussed below) would eliminate this advantage and "even the playing field" on which interfirm bidders and target managers compete. This result would comport with Congress' goal of regulatory neutrality ${ }^{10}$ and would also facilitate a more efficient allocation of target assets. ${ }^{11}$

Central to both propositions is the coerciveness that we ascribe to defensive open market repurchases. We devoted much of our article to a formal

\footnotetext{
8. Bradley \& Rosenzweig, supra note 1, at 1393-98, 1401-04.

9. Id. at 1396-99.

10. See id. at $1406-07$.

11. See id. at 1408-11.
} 
demonstration of that coerciveness; here we will try to illustrate it more briefly and intuitively.

Consider, in the context of a value-increasing interfirm tender offer, the time-series behavior of the market price of target shares. We assume that the pre-offer market price of the target shares reflects the value of the target's resources in their current allocation, i.e., under the direction of the current target managers. By definition, the announcement of a valueincreasing tender offer will raise the market price of target shares above its pre-offer level. The post-announcement but pre-execution market price of the target shares will reflect the terms of the bid and the probability that the offer will be accepted. Assuming that all target shareholders will tender their shares, the post-announcement but pre-execution market price of the target shares will be:

(1) $\mathrm{P}=[\mathrm{F} \times \mathrm{Pt}]+[(1-\mathrm{F}) \times \mathrm{Pe}]>\mathrm{Po}$

where

$\mathbf{P}=$ the post-announcement, pre-execution market price of the target shares;

$\mathrm{P}_{\mathrm{t}}=$ the per share offer price;

$\mathrm{Pe}=$ the expected post-execution market price of the target shares not purchased;

Po $=$ the pre-offer market price of the target shares; and

$F=$ the fraction of the target shares sought by the bidding firm. ${ }^{12}$

Suppose that after the announcement of the interfirm bid, when the market price has increased to reflect the premium of that bid, target managers embark on an open market repurchase program. Specifically, assume that the target managers announce that they will buy a significant fraction of the target shares in the open market at the prevailing market (supply) price. Under these conditions, the supply price of the target shares will be the expected value of the outstanding offer, or $P$ in Equation (1).

Consider now the response of a fully informed target shareholder to the outstanding interfirm bid and the defensive open market repurchase program. The choice facing the target shareholder is either to tender to the interfirm bidder and realize an expected value of $\mathrm{P}$ per share, or to sell the shares in the open market, which is equivalent to selling them back to the target firm, again at a price equal to P. Target shareholders (or market arbitrageurs) ${ }^{18}$ would realize that if the target managers repurchase a significant fraction of the target shares at a premium relative to the pre-

12. Bradley, Interfirm Tender Offers and the Market for Corporate Control, 53 J. Bus. 345, 353 (1980). For a discussion of the assumptions on which this model depends, see Bradley \& Rosenzweig, supra note 1, at 1391-93.

13. See Bradley \& Rosenzweig, supra note 1, at 1393 n.60. 
offer price, the remaining unpurchased shares will sell at a discount relative to the same benchmark. ${ }^{14}$ In addition, they would understand that the repurchase will be effected on a first-come, first-served basis; only those target shareholders who move quickly enough to participate in the repurchase program will receive the expected value of the takeover ( $\mathrm{P}$ in Equation (1)). Those who are unable to sell their shares back to the target will suffer a capital loss. Thus, nonparticipating shareholders will in effect finance the premium that is paid to the selling shareholders in the open market buyback.

In sum, a defensive open market repurchase program is equivalent to a first-come, first-served, premium tender offer. As a result, target shareholders will be pressured to sell their shares to the target managers rather than tender to the interfirm bidder, even though the interfirm tender is at a substantial premium.

The implications of the above analysis are clear. Defensive open market repurchase programs should be prohibited because they exert precisely the pressures on target shareholders that Congress intended to eliminate by adopting the Williams Act. ${ }^{13}$ Moreover, target managers can use such transactions to defeat value-increasing bids, which gives those managers an advantage over interfirm bidders that undermines the Congressional goal of regulatory neutrality ${ }^{16}$ and impedes an efficient allocation of corporate resources. ${ }^{17}$

\section{B. The Gordon and Kornhauser Criticism}

Although Gordon and Kornhauser agree with our proposal to bar defensive open market repurchase programs, they nevertheless feel compelled to show that, contrary to our analysis, such transactions need not "distort shareholder choice."18 In other words, they purport to demonstrate that a defensive open market repurchase program need not effect a wealth transfer from non-selling to selling shareholders.

To make their point, Gordon and Kornhauser focus on the way that target managers finance a defensive stock repurchase. They assert, in our view implausibly, that most (all?) share repurchases are financed through the sale of target assets, and then argue that the profitability of such asset

14. Algebraically, if $\mathbf{F}$ of the target shares are repurchased at a premium $R$, then subsequent to the repurchase the remaining $(1-F)$ of the firm's shares will trade at a discount of $(F \times R) /(1-F)$.

As we noted in our article, this analysis assumes, consistent with existing empirical evidence, that the target's value under current management will not be affected by announcement of either the interfirm bid or the repurchase offer. See Bradley \& Rosenzweig, supra note 1, at 1395 n.63.

15. See Bradley \& Rosenzweig, supra note 1, at 1401-04.

16. Id. at 1406-07.

17. Id. at 1408-11.

18. Gordon \& Kornhauser, supra note 2, at 304. 
sales can increase the value of the firm. ${ }^{19}$ More particularly, they claim that the profits from an asset sale can sometimes increase the value of the firm to a level equivalent to the value of the premium interfirm bid. If the asset sale generates profits sufficient to increase the value of target shares to $P$ in Equation (1), they say, then purchasing shares in the open market at that price will not impose a capital loss on the non-selling shareholders. As a result, they conclude, target management's open market repurchases will not be coercive. ${ }^{20}$

Under the conditions they specify, of course, Gordon and Kornhauser are correct. But the problem with their analysis should be obvious even to those only casually acquainted with principles of financial economics. Gordon and Kornhauser confuse the firm's financing decisions with its investment/production decisions. Naturally, if the firm can increase its value by selling off assets, then the repurchase may be non-coercive. Indeed, in our article we explicitly qualified our analysis by assuming unchanged investment/production decisions and therefore a constant firm value. ${ }^{21}$ As we noted, a target's management is always free to change its investment/production decisions in an effort to increase the target's value and thereby defeat an unwanted takeover bid, although empirical evidence suggests that this does not often happen. ${ }^{22}$

Gordon and Kornhauser cannot understand why target managers might find defensive open market repurchases useful for hindering interfirm bids because they imagine that such managers have up their sleeves an inexhaustible supply of value-increasing investment/production strategies (including the ability to generate the synergistic gains contemplated by the bidder). But if this were true, we would expect targets that successfully preserve their independence to fare much better than they apparently do. ${ }^{23}$ In this case, therefore, the familiar analytical mode of financial economics-holding investment/production decisions constant-is especially compelling. ${ }^{24}$

19. Id. at 303-05.

20. Id.

21. See Bradley \& Rosenzweig, supra note 1, at 1395 n.63, 1420 n.152, 1421 n.154, 1426 n.169. See also supra note 14 (repeating assumption). Thus, contrary to Gordon and Kornhauser's assertion, our analysis does not assume a mismanaged asset sale or, for that matter, any asset sale at all. See Gordon \& Kornhauser, supra note 2, at 303.

22. See Bradley \& Rosenzweig, supra note 1, at 1389 n.51 (describing empirical studies demonstrating that value of target that preserves its independence generally does not exceed pre-bid value).

23. Id. Interestingly, Gordon and Kornhauser offer no explanation for the one case for which reliable data are available-the Carter Hawley Hall defensive open market repurchase program. In that case, shareholder response and the price behavior of the target's shares matched the predictions of our analysis and compellingly demonstrated the effectiveness of defensive open market repurchases. See id. at 1398 n.69.

24. In addition, if their purpose is to examine all possible results of an asset sale, Gordon and Kornhauser's analysis seems incomplete. Thus, an asset sale could in fact generate profits in excess of the premium offered by the bidding firm. Gordon and Kornhauser acknowledge this possibility, but 


\section{Defensive Self-Tender Offers}

\section{A. Review of the Bradley and Rosenzweig Analysis}

We argue that defensive self-tender offers should be permitted, subject to certain restrictions. Allowing defensive self-tenders tends to "even the playing field" in control contests by permitting target managers to compete on an equal footing with the managers of bidding firms. A fair competition between the managers of targets and bidders for the right to control the target's resources will lead to the optimal allocation of those resources. $^{25}$ This result, moreover, is consistent with the policy of evenhandedness that Congress favored in regulating tender offers. ${ }^{26}$ We therefore conclude that interfirm bids and defensive self-tenders should be regulated alike. Thus, taking the basic regulatory scheme of the Williams Act as given, we argue that the same restrictions should apply to both types of tender offers. ${ }^{27}$

If not subjected to certain additional restrictions, however, target managers would still enjoy a significant competitive edge against interfirm bidders. Specifically, we showed in our article that defensive self-tenders could defeat even value-increasing interfirm bids if target managers were permitted either (1) to seek fewer shares than the number sought by the interfirm bidder ${ }^{28}$ or (2) to exclude the bidder from participating in the self-tender. ${ }^{29}$ Accordingly, we proposed to bar defensive self-tenders that either exclude the bidder ${ }^{30}$ or seek fewer shares than the bidder has sought.

As long as defensive self-tenders were thus regulated, they would re-

conclude without explanation that "[i]t seems improbable . . . that very many target managements will be successful in this way." Gordon \& Kornhauser, supra note 2, at 306 n.30. Absent further explanation, it is not clear under the Gordon and Kornhauser analysis why defensive stock repurchases can "never increase shareholder wealth." Id. at 306.

Gordon and Kornhauser claim further that their "analysis also applies where the repurchase is financed through the target's cash on hand, or, in a more complex form, where it is financed through debt." Gordon \& Kornhauser, supra note 2, at 303 n.22. This claim is simply incorrect. Assuming unchanged investment/production decisions, financing the repurchase with cash on hand or additional debt will have no effect on the total value of the target resources. Indeed, our analysis of defensive open market repurchases assumes that such repurchases would be financed with cash on hand or new debt and, as we show, such repurchases are in fact coercive. See supra notes 13-15 and accompanying text; Bradley \& Rosenzweig, supra note 1, at 1393-98.

25. Bradley \& Rosenzweig, supra note 1, at 1408-12.

26. Id. at $1406-08$.

27. See id. at $1407 \&$ n.102 (noting recent Securities and Exchange Commission (SEC) rule amendments designed to eliminate distinctions in the regulation of interfirm bids and self-tenders).

28. Id. at 1421-23. See also AC Acquisitions Corp. v. Anderson, Clayton \& Co., Civ. No. 8584, n.11 (Del. Ch., Sept. 18, 1986) (preliminarily enjoining defensive self-tender that sought fewer shares than number sought by interfirm bidder).

29. Bradley \& Rosenzweig, supra note 1, at 1423-27.

30. The SEC recently amended Rule $13 e-4,17$ C.F.R. $\$ 240.13 e-4$ (1986), to bar such discrimination. See Amendments to Tender Offer Rules, Exchange Act Release No. 23,421 [Current Binder] Fed. Sec. L. Rep. (CCH) I 84,016 (July 11, 1986). 
present an important safeguard against corporate raids-that is, bidder attempts to expropriate target shareholder wealth-but not a mechanism by which managers could block desirable asset redeployments and deprive their shareholders of substantial premiums. In other words, target managers could use self-tenders to solve the prisoner's dilemma that might otherwise pressure target shareholders into accepting a value-decreasing bid, ${ }^{31}$ but they could not use them to defeat value-increasing acquisitions. ${ }^{32}$ The result would be the more even playing field that we favor.

In our article, we noted a serious objection to our proposal. Because the appraisal remedy and fair-price charter provisions preclude interfirm bidders (but of course not target managers) from undertaking a second-step takeout merger at less than the pre-offer market price of target shares, it follows that even under the above conditions, self-tendering target managers might enjoy a competitive advantage that would permit them to defeat value-increasing interfirm bids. ${ }^{38}$ We also responded briefly to this objection. ${ }^{34}$ First, we noted that the appraisal remedy and fair-price charter provisions in fact constrain interfirm bidders only to the extent that a takeout merger is likely. We observed that bidder attempts to expropriate target wealth through self-dealing may be less detectable than some believe, which makes back end takeouts far less than inevitable. Second, we suggested that it may make sense simply to nullify the appraisal remedy and fair-price provisions once target managers have effected a defensive self-tender offer. ${ }^{35}$

\section{B. The Gordon and Kornhauser Criticism ${ }^{36}$}

Gordon and Kornhauser attack both of our responses to the appraisal remedy "problem" originally identified by us. First, they say that second-

31. See Bradley \& Rosenzweig, supra note 1, at 1412-17.

32. See id. at 1417-28.

33. Id. at 1419 n.150.

34. Id.

35. In our article, we did not consider the distinction between legislatively-adopted fair-price provisions and those that are effected by charter amendment, with shareholder approval. Upon further reflection, sharcholder-approved provisions concern us less than those mandated by legislatures, although not because our analysis pertains less to the former than the latter. Rather, we are reluctant to advance a policy prescription that might constrain the "contract" into which shareholders may voluntarily enter. While some might challenge this reluctance by suggesting that infirmities in shareholder voting may justify constraints that are designed to ensure "fairness" for shareholders, analysis of this issue is beyond the scope of this reply. See generally R. LEMPERT \& J. SANDERS, AN INvitation TO LAw AND Social Science 306-39 (1986) (discussing collective action and free rider problems). Thus, since our thesis (like the Gordon and Kornhauser critique) deals primarily with the statutory appraisal remedy, we will omit further discussion of fair-price charter amendments.

36. In view of our disagreement with Gordon and Kornhauser regarding the relevance of financing decisions to an analysis of defensive stock repurchases, see supra Part II.B., we do not respond to their claim that the target's sale of "special synergy assets" to finance a defensive self-tender may result in decreased shareholder wealth. See Gordon \& Kornhauser, supra note 2, at 307. Instead, we 
step takeout mergers are virtually inevitable, particularly in view of fairprice charter provisions designed to force takeouts in the event of selfdealing. ${ }^{37}$ Second, and more significantly, they claim that nullifying the appraisal remedy in the event of a defensive self-tender would clash with the very justification for that protection. ${ }^{33}$

We disagree on both counts. With regard to the likelihood of a secondstep takeout merger, Gordon and Kornhauser simply repeat Professor Carney's assertion that such a takeout is highly probable. Like Professor Carney, however, they offer no evidence for their belief that wealth expropriation through self-dealing cannot go undetected. ${ }^{39}$ It is questionable whether even the most carefully drafted charter provision could define self-dealing sufficiently precisely or artfully to make takeouts as common a consequence of wealth expropriation as Gordon and Kornhauser claim. Indeed, as Professor Bebchuk notes, "those instances in which the acquirer decides against an immediate takeout are exactly the instances in which the acquirer expects that, by diverting earnings or effecting a distant takeout, it will leave minority shareholders with even less than it would have to pay them in an immediate takeout."40 Thus, we continue to believe that acquiring firms have considerable freedom to self deal with controlled but only partially owned subsidiaries. ${ }^{11}$

confine our discussion to their "more general and direct objection[s] to self-tenders." Id.

One such objection is the Gordon and Kornhauser claim that "[a] management competition argument is a poor justification" for defensive self-tenders. Id. Specifically, Gordon and Kornhauser argue that our reliance on the competition argument is inappropriate because (1) the bidder's willingness to make a premium offer suggests that target management has already lost the competition, and (2) selftendering target managers are using shareholders' money rather than their own to fight off the interfirm bidder. Id. Neither point is persuasive.

First, we noted repeatedly in our article that defensive self-tenders should be available to protect target shareholders against value-decreasing bids. See, e.g., Bradley \& Rosenzweig, supra note 1, at 1412-28. Gordon and Kornhauser's focus on premium bids entirely misses this point, and also ignores our assertion that defensive self-tenders (subject to our conditions) could defeat premium bids only where changed investment/production decisions or exogenous economic changes increase the target's value above the value of the interfirm bid. See id. at $1421 \mathrm{n} .154,1426 \mathrm{n} .169$. Second, their concern that self-tenders can "dissipate target assets and impose deadweight transaction costs" is, in their words, "not . . . an objection to self-tenders per se, but to the preceding asset sale, which could have occurred anyway." Gordon \& Kornhauser, supra note 2, at 307 . In this respect, it is immaterial that self-tendering target managers do not put up their own funds. All contestants in the market for corporate control (including managers who attempt a management buyout) must finance their cfforts in some way. If target managers finance a self-tender through an inappropriate asset sale, they will face potential claims of fiduciary breach from their shareholders. But that would be true whether or not the inappropriate asset sale were undertaken to finance a self-tender. Gordon and Kornhauser's real concern here is mismanaged asset sales, not defensive self-tenders.

37. Gordon \& Kornhauser, supra note 2, at 309.

38. Id.

39. See Carney, Shareholder Coordination Costs, Shark Repellents, and Takeout Mergers: The Case Against Fiduciary Duties, 1983 AM. B. Found. REs. J. 341, 380-81.

40. Bebchuk, Toward Undistorted Choice and Equal Treatment in Corporate Takeovers, 98 HARv. L. REv. 1693, 1713 (1985).

41. At least one noted commentator has suggested that "the weight of academic opinion" favors . this view. R. Gilson, The Law and Finance of Corporate Acquisitions 928 (1986). 
But let us assume arguendo that Gordon and Kornhauser are correct about the likelihood of a second-step takeout merger. This permits us to respond to what we take to be their central criticism of our proposal, namely that abrogating appraisal rights, as we suggest, is "highly controversial"42 and "would defeat their express purpose."43 We can state our disagreement with Gordon and Kornhauser on this point rather simply: They believe that our proposal is radical and inconsistent with the purposes that underlie the appraisal remedy. We believe, upon reflection, that our proposal is far less radical than it seems and, in any event, quite consistent with the conventionally accepted justifications for appraisal.

Let us discuss the latter point first. Why do corporate statutes commonly give dissenting shareholders the right to be bought out at "fair value" when their corporation effects certain major transactions, such as mergers, substantial asset sales, and material charter amendments? Originally, of course, states created appraisal rights as a sort of quid pro quo for abandonment of the historical rule requiring unanimous shareholder consent to these sorts of transactions. ${ }^{44}$ The contemporary arguments for the appraisal remedy, however, address the ends now thought to be served by the remedy. For present purposes, two suggested rationales for appraisal are worth noting. ${ }^{65}$ The first is that shareholders should be able to cash out their investment rather than be forced into a venture that is very different from the one in which they originally invested. If, for example, an investor buys shares in a grocery store chain that is later merged into a much larger conglomerate only a fraction of whose activities will be in the food industry, the investor should have a means of cashing out at a fair

In addition, efforts to force takeouts by defining self-dealing more broadly in fair-price charter provisions may disable controlling shareholders from effecting even innocuous transactions with their subsidiaries, which seems counterproductive. $C$. Amalgamated Sugar Co. v. NL Industries, [Current Binder] Fed. Sec. L. Rep. (CCH) I 92,857 (S.D.N.Y., Aug. 5, 1986) (invalidating "poison pill" plan that, inter alia, barred certain transactions between company and 20\%-or-greater shareholder).

42. Gordon \& Kornhauser, supra note 2, at 311.

43. Id. at 309 .

44. See, e.g., R. Clark, Corporate Law 443-44 (1986); Carney, Fundamental Corporate Changes, Minority Shareholders, and Business Purposes, 1980 AM. B. Found. REs. J. 69, 94-97 [hereinafter Fundamental Corporate Changes]; Manning; The Shareholder's Appraisal Remedy: An Essay for Frank Coker, 72 YALE L.J. 223, 228-29 (1962).

45. See generally R. ClaRK, supra note 44, at 444-49; (discussing justifications for appraisal remedy); Fundamental Corporate Changes, supra note 44, at 88-94 (same); Fischel, The Appraisal Remedy in Corporate Law, 1983 AM. B. Found. REs. J. 875, 877-78 (same); Kanda \& Levmore, The Appraisal Remedy and the Goals of Corporate Law, 32 UCLA L. REv. 429, 433-45 (1985) (discussing goals of appraisal remedy).

Commentators often mention these two rationales as part of the "conventional view" regarding appraisal. Many have criticized these justifications as lacking in explanatory power and have offered alternative explanations. See, e.g., Fischel, supra, at 877-78; Kanda \& Levmore, supra, at 434, 437-45. Since we write here primarily in response to the Gordon and Kornhauser critique, we leave for another day discussion of these criticisms and alternatives. Thus, we confine ourselves to the Gordon and Kornhauser analysis, and argue that our proposal regarding appraisal makes sense even accepting their view of the purposes served by that remedy. 
price, so that he may reinvest in a venture more likely to satisfy his original investment goals and expectations. ${ }^{46}$

Whether or not investors really have the expectations ascribed to them by this theory, ${ }^{47}$ it simply does not apply to second-step takeout mergers, where the shareholder by definition is cashed out and thus retains no continuing investment in the merged firm. This leads us to the second conventionally asserted justification for appraisal and, indeed, the only justification noted by Gordon and Kornhauser: Since a rule requiring majority rather than unanimous shareholder consent for the approval of certain transactions creates the potential for expropriation of minority shareholder wealth by a firm's majority shareholders, a remedy is needed to mitigate the risk that minority shareholders will be treated unfairly in such a transaction. ${ }^{48}$

The relevance of the appraisal remedy (and this justification for it) to acquisitions by tender offer stems from the two-step nature of these transactions. Frequently, bidders make tender offers for a controlling fraction of the target's outstanding shares. ${ }^{49}$ Once the bidder has obtained "control," it often effects a merger with the target firm. In this context, the role of the appraisal remedy is to guarantee that the price paid in the second stage is "fair," which usually means not significantly below the price paid in the first stage. ${ }^{.00}$

46. R. ClaRK, supra note 44 , at 444.

47. Some (for example, financial economists) would argue that modern investors are concerned only with the risk and return offered by their investments. See R. Brealey \& S. Myers, Principles of Corporate Finance 117-63 (2d ed. 1984). On the other hand, a merger or other major change can significantly alter the risk and return of the shareholders' original investments. Moreover, under existing law investors certainly expect that appraisal rights will attach in the event of extraordinary corporate transactions. As Professor Clark observes, however, "[w] hat this debate shows us is that people's expectations may adjust to whatever assignments of rights and duties the law in fact imposes. In such a context, it requires a different set of considerations than people's actual expectations to decide which expectations the law ought to encourage." R. CLARK, supra note 44, at 444-45.

48. See Gordon \& Kornhauser, supra note 2, at 309.

49. See, e.g., Office of The Ghief Economist, SEC, The Economics of ANy-OR-Ali., ParTIAL AND Two-Tier Tender Offers (1985) [hereinafter SEC STUdy]; see also Bradley \& Rosenzweig, supra note 1, at 1390 n.54 (explaining differences between two-tier, partial, and any-or-all bids). Indeed, even with any-or-all bids, where the bidder seeks up to $100 \%$ of the target's shares, a control-winning bid will rarely (one is tempted to say never) attract all of the target shares; there are always holdouts for one reason or another. See id. at 1391 n.56. Thus, even where the bid is not expressly "two-tier" or "partial," a successful bid almost always leaves a fraction of the target's shares unpurchased. Moreover, these unpurchased shares generally trade at a discount relative to the offer price. See SEC STUDY, supra, at 24 \& Tables 4a, 5, \& 9. In this respect, Gordon and Kornhauser may be overly optimistic in asserting that "the any-or-all interfirm bid does not present the distorted shareholder choice problems that concern Bradley and Rosenzweig ...." Gordon \& Kornhauser, supra note 2, at 308 n.33.

50. Professor Fischel, for example, sees the appraisal remedy as a solution to the prisoner's dilemma that could confront target shareholders, since it precludes bidders from paying a substantial premium for a controlling interest and then freezing out the remaining minority interest at a significantly lower price. Fischel, supra note 45, at 879; see also Bradley \& Rosenzweig, supra note 1, at 1414 (noting constraining influence of appraisal statutes against potential corporate raiders). 
Gordon and Kornhauser believe that target shareholders need the protection that appraisal affords, even in the context of a defensive selftender. Evidently, they fear that if control-winning bidders were not constrained by appraisal statutes, they could harm target shareholders by freezing them out at an unfair price. Gordon and Kornhauser therefore criticize us for proposing to nullify the appraisal remedy in circumstances that seem to invoke its very purpose.

Our disagreement with Gordon and Kornhauser on this point is as basic as it is clear. They find nullification of the appraisal remedy in the context of defensive self-tenders inconsistent with the purpose of protecting target shareholders against the unfairness of this kind of wealth expropriation. We believe such protection is unnecessary in this setting and that, ironically, preserving the appraisal remedy threatens great potential harm to the very shareholders whose protection is at stake.

Eliminating defensive self-tenders from target management's arsenal, we argue, could harm target shareholders by making their firm more vulnerable to value-decreasing bids. But we also recognize that target shareholders would be ill-served by rules permitting target managers to defeat value-increasing bids; hence we propose the conditions for defensive selftenders noted above. ${ }^{51}$ Gordon and Kornhauser, as we just noted, reject one of those conditions-nullification of the appraisal remedy-as radical and conceptually unjustified, and they implicitly criticize the other two as difficult and cumbersome. ${ }^{\mathbf{3 2}}$ But their real disagreement is with our basic assertion that defensive self-tenders are a valuable means of protecting target shareholders against value-decreasing bids. Since they do not share our belief that the availability of defensive self-tenders helps deter corporate raiding, they conclude that our proposal carries some very real costs but offers only illusory benefits. ${ }^{33}$ We claim not only that the asserted benefits of defensive self-tenders are real, but that the costs are either justified or not nearly as substantial as Gordon and Kornhauser would suggest.

These two points, of course, are closely related. First, what are the costs that trouble Gordon and Kornhauser? Apart from the cumbersome nature of our conditions (to which we will return), their concern seems to be that eliminating appraisal would harm target shareholders. But that is simply untrue, if one accepts our claim regarding the value of defensive selftenders. In other words, if defensive self-tenders (subject to our conditions) help prevent raids, then the protections ordinarily afforded by appraisal are unnecessary in the context of such self-tenders. In the final analysis,

51. See supra text accompanying notes 28-30.

52. See Gordon \& Kornhauser, supra note 2, at 309, 311.

53. Id. at 311 . 
therefore, we must return to that basic question: Are defensive self-tenders really a valuable weapon for deterring value-decreasing bids?

Gordon and Kornhauser's skepticism regarding the value of defensive self-tender offers derives from their confidence that other mechanisms adequately deter potential corporate raiders. In other words, they do not dispute our claim that defensive self-tenders, subject to the conditions we propose, can defeat value-decreasing but not value-increasing bids. Rather, they claim that the conditions we suggest would exact too high a price for a safeguard that is, in their view, redundant at best. ${ }^{54}$

Since we disagree that the function we attribute to defensive self-tenders is reliably performed by other mechanisms, we naturally come to different conclusions regarding the value of defensive self-tenders and the acceptability of our conditions. Again, this is not unexplored territory; in our article we considered the claim now repeated by Gordon and Kornhauser-that legal rules (i.e., appraisal statutes and the common law of fiduciary responsibility) and competition in the market for corporate control effectively prevent raiding - and we concluded that these alternatives do not offer sufficient protection. ${ }^{5 s}$ In order to respond to Gordon and Kornhauser, we will expand on our earlier discussion.

Gordon and Kornhauser say that movements in the price of target shares will attract other potential bidders in the event of a valuedecreasing bid. ${ }^{B B}$ But they simply ignore our argument that the incentive of firms to compete in the market for corporate control may well be reduced because of the peculiar attributes of that market. In a corporate control contest, all potential acquisition gains could be dissipated rather than captured by any competitor, even the winner, since competition generally consists of a series of revised (and costly) bids that are made before any target shares are actually purchased. ${ }^{57}$ Contrary to Gordon and Kornhauser's assertion, this does not necessarily mean that there is "large scale failure" ${ }^{38}$ in this market; it does suggest, however, that competition in this market is sufficiently imperfect to justify the availability of other deterrents to corporate raids. ${ }^{\text {s9 }}$

\footnotetext{
54. Id. at 309-11.

55. Bradley \& Rosenzweig, supra note 1, at 1412 n.129, 1414-17.

56. Gordon \& Kornhauser, supra note 2, at 310.

57. Bradley \& Rosenzweig, supra note 1 , at 1415-16.

58. Gordon \& Kornhauser, supra note 2, at 310.

59. See also Carney, Two-Tier Tender Offers and Shark Repellents, 4 Midiand CoRP. Fin. J. 48,52 (1986) (arguing that potential second bidders may be discouraged from competing by recognition that first bidder will disregard its sunk costs in deciding whether to raise its bid). Gordon and Kornhauser also criticize us for "hypothesiz[ing] a situation in which target management [knows] of the bidder's nefarious back end intentions (and so would be justified in initiating a self-tender), but the market [does] not . . . ." They argue that such a "scenario seems, in general, highly implausible." Gordon \& Kornhauser, supra note 2, at 310.

We hypothesize no such situation. Rather, we rely on management's interest in preserving its con-
} 
Gordon and Kornhauser also question (at least implicitly) our unwillingness to rely on fiduciary obligations and appraisal statutes to prevent value-decreasing bids. ${ }^{\circ 0}$ But there can be little doubt, in view of decisions such as Sinclair Oil Corp. $v$. Levien, ${ }^{61}$ that the law of fiduciary responsibility permits a parent corporation to engage in considerable irremediable self-dealing with its subsidiary, to the detriment of the subsidiary's minority shareholders. ${ }^{62}$ Moreover, commentators other than Gordon and Kornhauser have long acknowledged the imperfections of the appraisal remedy. ${ }^{\text {s3 }}$ Against this substantial commentary, Gordon and Kornhauser offer very little to justify their apparent confidence in appraisal.

We again urge caution, therefore, to those who would conclude that the benefits provided by defensive self-tenders are illusory and at best redundant. If, as we believe, the alternative mechanisms on which some would rely to deter raiding bids are inadequate, then the benefits of defensive self-tenders are quite real, and the ban proposed by Gordon and Kornhauser would in fact harm target shareholders. In addition, nullifying the appraisal remedy in the context of a defensive self-tender should cause little concern, since the function ordinarily performed by appraisal-protecting target shareholders against wealth expropriation-would be performed by the self-tender. ${ }^{64}$

Note again, moreover, that defensive self-tenders pose real dangers unless the appraisal remedy is inoperative. Thus, as we have demonstrated elsewhere, ${ }^{\mathrm{BD}}$ the existence of appraisal rights would constrain bidders but not target managers, thus enabling the latter to "front end load" their self-tender and thereby defeat even value-increasing interfirm bids. ${ }^{86}$ Iron-

trol over the target as the principal motivation for a defensive self-tender. Bradley \& Rosenzweig, supra note 1, at 1416. Moreover, Gordon and Kornhauser's claim that target management can simply inform the market of the bidder's nefarious character (where that information does happen to be known) is questionable. Mere announcements (as compared with a competing bid) are unlikely to move the target's share price sufficiently to solve the prisoner's dilemma that would confront shareholders as a result of a raiding bid.

60. See Gordon \& Kornhauser, supra note 2, at 300 \& n.15, 309 \& n.37.

61. 280 A.2d 717 (Del. 1971).

62. Id. at 720; see also R. GiLson, supra note 41, at 928-29; AMERIcAN LAw InSTtTUTE, PRINCiples of Corporate Governance: Transactions in Control 26 n.10 (Reporters' Study No. 1, Feb. 22, 1985) (hereinafter A.L.I. REPORTERS' STUDY]; Bradley \& Rosenzweig, supra note 1, at 1412 n.129 (parent company often has opportunity to favor itself at expense of subsidiary's minority sharcholders).

63. See Bradley \& Rosenzweig, supra note 1, at 1415 n.135 (authorities cited); A.L.I. REPORTERs' STUdy, supra note 62, at 3-19; R. Clark, supra note 44, at 449-58; M. Eisenberg, The Structure of the Corporation 83 (1976); R. Gilson, supta note 41, at 885-87.

64. In this respect, eliminating appraisal in this setting would be far less radical than Gordon and Kornhauser suggest. There have long been provisions-for example, the stock-market exception, see, e.g., Det. CoDE ANN. tit. 8, § 262(b)(1) (1983)-denying appraisal in circumstances in which the remedy's protections are thought unnecessary.

65. Bradley \& Rosenzweig, supra note 1, at 1419 n.150; see also supra notes 33-35 and accompanying text.

66. Cf. Edelman v. Freuhauf Corp., 798 F.2d 882 (6th Cir. 1986) (enjoining target managers' 
ically, therefore, far from protecting target shareholders, preservation of the appraisal remedy in the context of a defensive self-tender could seriously harm them by facilitating the defeat of premium takeover bids. Target shareholders and, for that matter, society at large are better served by rules that help maintain an even playing field in corporate control contests. ${ }^{67}$

Finally, what about the Gordon and Kornhauser claims that the conditions $^{68}$ we would impose on defensive self-tenders are cumbersome and represent "changes . . . from present arrangements"? ${ }^{80}$ We concede both points (although we note that the SEC has now adopted one of our conditions-the bar against discriminatory defensive self-tenders-in its recent amendments to Rule $13 \mathrm{e}-4),{ }^{70}$ but we question the significance of these criticisms. Takeover defensive measures can pose real risks to target shareholders and society generally by impeding value-increasing takeovers. ${ }^{71}$ We think it appropriate that defensive responses be subjected to restrictions (even cumbersome restrictions) designed to disable managers from thwarting such acquisitions. Given the self-interest that often motivates resistant target managers, ${ }^{72}$ this does not seem objectionable.

\section{Alternative Reforms of the-Appraisal Remedy in ConTrol Contests}

As we have noted, our proposal to disable target shareholders from seeking appraisal in the context of a defensive self-tender derives from our preference for an "even playing field" in corporate control contests: The existence of appraisal rights seriously disadvantages interfirm bidders in their competition against self-tendering target managers. In order to emphasize this point-that our concern is evenhandedness rather than repeal of the appraisal remedy per se-we conclude this reply by briefly describ-

attempt to exempt leveraged buyout proposal from appraisal provisions, on ground that exemption would unfairly disadvantage competing interfirm bidder).

67. For recent decisions discussing the importance of an "even playing field" in corporate control contests, see Hanson Trust PLC v. ML SCM Acquisition, Inc., 781 F.2d 264, 283 (2d Cir. 1986) (enjoining "lock-up option" on ground that it inappropriately favored one bidder); Revlon, Inc. v. MacAndrews \& Forbes Holdings, 506 A.2d 173, 184 (Del. 1986) (same with respect to "no-shop" provision).

68. See supra notes $28-30$ and accompanying text.

69. Gordon \& Kornhauser, supra note 2, at 311.

70. See Exchange Act Release No. 23,421, [Current Binder] Fed. Sec. L. Rep. (CCH) II 84,016 (July 11, 1986).

71. See Easterbrook \& Fischel, The Proper Role of a Target's Management in Responding to a Tender Offer, 94 HaRv. L. Rev. 1161, 1175 (1981); Gilson, A Structural Approach to Corporations: The Case Against Defensive Tactics in Tender Offers, 33 STAN. L. REv. 819, 825 (1981); Rosenzweig, Target Litigation, $85 \mathrm{MICH}$. L. REv. (forthcoming 1986).

72. See authorities cited supra note 71 (discussing target management's conflict of interest); see also Coffee, Shareholders Versus Managers: The Strain in the Corporate Web, 85 Mich. L. REv. (forthcoming 1986) (same). 
ing three alternative reforms of the appraisal remedy that would accomplish the desired result of preserving a fair competition between bidders and target managers with less radical change from the status quo. We do not mean to suggest that any of these alternatives is superior to our original proposal; they should, however, allay the concerns of those who fear that nullifying the appraisal remedy is too drastic a "change[] . . . from present arrangements."

\section{A. Ex Ante Appraisal}

One alternative to nullifying the appraisal remedy would be to require bidders to offer to buy any and all target shares at the pre-offer price. Under this alternative, which we label "ex ante appraisal," bidding firms would be forced to stand ready to pay the pre-offer market price for all shares tendered. Put differently, this proposal would allow target shareholders either to sell their holdings to the bidder at the pre-offer price or to participate in the outstanding tender offer. A target shareholder electing to participate in the tender offer would be precluded from seeking appraisal for the shares not purchased by the bidder in the first stage of the offer.

Obviously, target shareholders believing that the sum of the first and second stages of a two-tier offer is likely to be less than the pre-offer value of their holdings would elect under this proposal to sell all of their shares to the bidder at the pre-offer price. Those believing that the value of the offer probably exceeds the pre-offer price would eschew the option to sell their holdings at this price and elect instead to participate in the tender offer. Under this scheme, shareholders would be protected from valuedecreasing bids; at the same time, bidders would be able to make frontend-loaded tender offers unconstrained by the appraisal remedy.

\section{B. Blended Appraisal}

A second alternative to appraisal, suggested by Professor Fischel, ${ }^{74}$ would be to calculate the appropriate remedy relative to the blended price paid by the bidding firm, which is $P$ in Equation (1). ${ }^{75}$ This alternative proposal exploits the fact that under current regulations, oversubscribed offers must be effected on a pro rata basis. ${ }^{78}$

One can think of this proposal as applying the appraisal remedy to

73. Gordon \& Kornhauser, supra note 2, at 311.

74. Fischel, supra note 45 , at 897 .

75. See supra note 12 and accompanying text.

76. 17 C.F.R. $\$ 240.14 d-8$ (1986). Thus, assuming $100 \%$ subscription, $P$ in Equation (1) would be equal to the price that each target shareholder would receive from tendering. 
total shareholder wealth, rather than the price of the firm's stock. This approach is sensible, since it is the wealth of the firm's shareholders rather than the price paid on the "back end" that is most relevant to concerns regarding fairness to target shareholders. As long as the weighted average of the prices paid by the bidder on the front and back ends of the offer exceeds the pre-offer price of the target shares, the offer will enhance the wealth of target shareholders regardless of the price paid on the back end. Indeed, under this proposal, the wealth of target shareholders could increase even if the back end price were literally zero.

This "blended appraisal" procedure would accomplish our goal of "evening the playing field" in corporate control contests by allowing bidders to front end load their bids to the same extent as target managers. Moreover, the proposal would effectively deter corporate raiders, who would be disabled from front end loading their bids so as to pay target shareholders a total amount equal to less than the firm's pre-offer value.

\section{Self-Appraisal}

A final alternative would be to allow target shareholders to seek an appraisal remedy in the wake of a successful defensive self-tender offer. Under this scheme, target managers would be required to stand ready to redeem, at the pre-offer price, the target shares not purchased in the defensive self-tender offer. To this end, target managers would be forced to seek outside financing to ensure that the premium repurchase (defensive self-tender) would not dilute the value of the remaining target shares. Thus, the managers of both the target and bidding firms would be forced to compete against each other in the same capital market for funds to finance their competing tender offers.

\section{Conclusion}

Gordon and Kornhauser note the "initial power"77 of our analysis but claim that "laborious unraveling"78 reveals its serious shortcomings. We have attempted to respond to their criticisms by extending our original arguments regarding the costs and benefits of defensive stock repurchases. In the process, we have argued that the conditions we would impose on defensive self-tender offers are sensibly designed to ensure that such transactions will be more beneficial than costly. Whether the result is an "appropriate use of law and economics models as a basis for policy prescriptions" ${ }^{\prime 39}$ is a judgment we leave to others.

77. Gordon and Kornhauser, supra note 2, at 311.

78. Id.

79. Id. 